\title{
'N EREDIENSHANDLEIDING
}

Book Title:

Handleiding vir die erediens

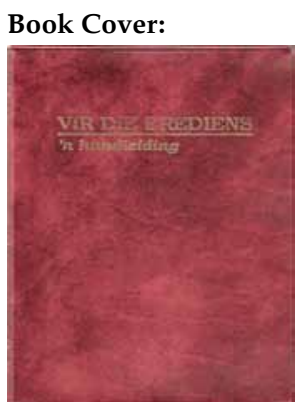

Authors:

Ferdi Clasen

André Bartlett

Cassie Carstens

Freddie Schoeman

André Agenbag

Deon Bester et al.

ISBN:

978-0-86487-471-9

\section{Publisher:}

Bybelmedia, Wellington, 2010, pp. 367, ZAR179.95*

*Book price at time of Review

Review Title:

'n Eredienshandleiding

\section{Reviewer:}

Cas J. Wepener ${ }^{1}$

\section{Affiliation:}

${ }^{1}$ Department of Practical Theology, University of

Pretoria, South Africa

email:

cas.wepener@up.ac.za

\section{Postal address:}

Department of Practical Theology, University of

Pretoria, Lynwood Road,

Hatfield 0083, South

Africa

How to cite this book review:

Wepener, C.J., 2010, "n

Eredienshandleiding',

HTS Teologiese Studies/

Theological Studies 66(1),

Art. \#998, 1 page. DOI:

10.4102/hts.v66i1.998

This review is available

at:

http://www.hts.org.za

(C) 2010. The Authors Licensee: OpenJournals

Publishing. This work

is licensed under the

Creative Commons

Attribution License. 'n Liturgis wat nooit die geleentheid kry om te kan meewerk aan 'n eredienshandleiding nie, is soos ' $n$ opgeleide soldaat wat nooit die geleentheid kry om te veg nie. Die skryf, samestelling en redigering van ' $n$ eredienshandleiding vra vir die praktiese toepassing van ' $n$ liturgis se vaardighede. Volgens Flip Theron wys ' $n$ teoloog se beskouing en hantering van die sakramente by uitstek sy of haar teologie. Dieselfde geld vir 'n erediendienshandleiding, want ' $n$ eredienshandling bied nie net riglyne vir viering aan nie, dit is ook die vertoonvenster van 'n kerk se teologie. Om 'n ou spreuk aan te haal, 'soos ons bid, so glo ons ook'.

In 2007 verskyn vir die NG Kerk onder leiding van die liturgis dr Ferdie Clasen as voorsitter van 'n redaksionele span, die proefbundel Vir die erediens. Hierdie proefbundel was bedoel om gebruik en geëvalueer te word deur liturge en liturgiste, sodat daaruit 'n meer finale produk saamgestel kan word om die Handboek vir die erediens uit 1988 te vervang. Na aanleiding van verdere radaksionele vergaderings, terugvoer uit gemeentes en enkele teologiese artikels wat die bundel geëvalueer het, het die redaksie en medewerkers Vir die erediens van 2007 verwerk as die Handleiding vir die erediens wat in Oktober 2010 by Bybelmedia verskyn het.

Wat dadelik opval van die nuwe handleiding is die netjiese afwerking en handige uitleg. Die handleiding is oorkoepelend verdeel in vier afdelings. Die eerste afdeling getiteld 'Die erediens' handel hoofsaaklik oor die Sondagse erediens, bied ruimskoots voorbeelde vir die elemente van die erediens, asook ' $n$ verskeidenheid formuliere wat ' $n$ hele paar Engelse vertalings van formuliere insluit soos byvoorbeeld vir die doop, nagmaal, openbare belydenis van geloof, die huwelik en vir ' $n$ begrafnis. Afdeling twee getiteld 'Ander dienste' bied 'n ryk verskeidenheid van voorbeeld-liturgieë vir dienste wat wissel van sangdienste en ekumensiese dienste, tot toewydingsdienste en klagdienste. Die derde afdeling handel spesifiek oor die kerklike jaar met liturgiese materiaal wat gebruik kan word vanaf Advent tot en met Sondag van Christus die Koning. Die laaste afdeling bevat die drie ekumeniese geloofsbelydenisse.

Hierdie vier afdelings en hulle spesifieke inhoud is ' $n$ duidelike bewys dat die vrug van die Liturgiese Beweging in die bundel verwerk is. Alhoewel daar heelwat dienste is wat die karakter van 'n soort hoër liturgiese tradisie het met ryke simboliek, gebede en formuliere uit die liturgie van die Vroeë Kerk en baie responsoriese elemente, is daar ook liturgiese voorstelle wat 'n vryer liturgiese tradisie beliggaam. Die eerste afdeling waarin die liturgiese elemente van die erediens (vanaf aanvangswoord tot seëngroet) met ' $n$ verskeidenheid voorbeelde aangebied word, is ' $n$ duidelike teken dat die handleiding nie aan een spesifieke liturgiese tradisie voorkeur wil verleen nie, maar dat dit oop en liturgies inklusief wil bly. Sodoende word gebruikers die geleentheid gebied om eredienste van ' $n$ verskeidenheid style binne die konteks van een denominasie aan te bied, vanaf klassiek-gereformeerde eredienste tot dienste in 'n lof- en aanbiddingsidioom. Opvallende elemente wat bygekom het in die 2010 publikasie sedert 2007 is onder andere dienste vir gebrokenheid, genesing en heling, 'n versoeningsdiens asook 'n omgewingsdiens om enkeles uit te sonder.

Alles in ag genome kan 'n mens net hoop dat hierdie nuwe eredienshandleiding vir die NG Kerk wyd ingang sal vind en sodoende die aanbidding van gemeentes sal verryk. Ten slotte is dit belangrik om op te merk dat, soos die redaksie dit in die inleiding uitdruklik stel, die proses nie met hierdie publikasie sal stop nie, maar dat dit 'n voortgaande en oop proses sal bly. Daarom sal ek as medewerker aan hierdie bundel, my enigste vraende opmerking wat ek ook aan Vir die erediens gestel het, omdat dit ook op hierdie nuwe bundel van toepassing is, hier herhaal as ' $n$ uitdaging vir hierdie voortgaande proses, naamlik of daar nie nog 'n rondte gedink kan word oor die aard en inkleding van 'n sogenaamde missionêre erediens nie. Desnieteenstaande is die nuwe Handleiding vir die erediens van 2010 in sy geheel beskou as ' $n$ werklik besondere bron wat die kerk in haar aanbidding kan help om God te aanbid en vir ewig te geniet. As ons sommige van die voorstelle ernstig neem en iets daarvan in gemeentes laat grondvat, kan hierdie bundel ook ten dienste staan van die blywende imperatief van kerkhereniging in die NG Kerk-familie. Soos Gerard Lukken dit in een van sy boeke stel: 'De liturgie is - ook in de eenwording van de kerken - een onvervangbare weg', en op op daardie weg is hierdie nuwe liturgiese bron 'n bron van hoop. 